\title{
Soil water extraction and photosynthesis in Gutierrezia sarothrae and Sporobolus cryptan- drus
}

\author{
CHANGGUI WAN, RONALD E. SOSEBEE, AND BOBBY L. MCMICHAEL
}

\begin{abstract}
Authors are postdoctoral research associate and professor, Dep. of Range and Wildlife Management, Texas Tech Univ., Lubbock 79409; and plant physiologist, USDA, Agricultural Research Service, Cropping Systems Res. Lab., Route 3, Lubbock, Texas 79409. The senior author is visiting scientist of Gansu Grassland Ecological Research Institute, Lanzhou, China.
\end{abstract}

\begin{abstract}
Broom snakeweed (Gutierrezia sarothrae Shinners), a C3 evergreen half-shrub, is a formidable competitor of grasses in the semiarid southwestern rangelands. Sand dropseed (Sporobolus cryptandrus (Torr.) Gray), perennial C4 bunchgrass, is the most drought resistant species in the short-grass prairie. A comparative study on soil water extraction patterns, photosynthesis, and canopy development in both species during spring-summer growing season of 1991 was conducted in pot-and field-grown plants. Sand dropseed extracts water at depths between 0 and $30 \mathrm{~cm}$ more effectively than broom snakeweed. In contrast, broom snakeweed can take up more water from the subsoil $(30-60 \mathrm{~cm})$ than sand dropseed. Photosynthesis in sand dropseed was more affected by soil water deficit than was broom snakeweed, which was related to their water extraction patterns. Leaf area accumulation of broom snakeweed was not affected by spring drought, but that of sand dropseed was reduced. Because of greater water extraction from the wetter subsoil by broom snakeweed during drought, it can assimilate more carbon and, therefore, prevail in a competitive relationship with sand dropseed.
\end{abstract}

Key Words: broom snakeweed, sand dropseed, soil water use, resource partitioning, half-shrub, warm-season grass

Contribution of the College of Agricultural Sciences, Texas Tech Univ. Financial support from USDA, Agricultural Research Service and the Institute for Plant Stress Research of Texas Tech Univ. (Project No. 6208-22230-001-01S) is gratefully acknowledged.

Manuscript accepted 29 Jan. 1992.
Soil water partitioning between shrubs and grasses has been established recently for several range species (Sala et al. 1989, Brown and Archer 1990). In a subtropical savanna of Texas, Brown and Archer (1990) showed that photosynthesis and stomatal conductance in deep-rooted honey mesquite (Prosopis glandulosa Torr. var. glandulosa) were closely coupled to soil moisture at depths between 30 and $90 \mathrm{~cm}$, while in shallow-rooted hooded windmillgrass (Chloris cucullata Bisch.), photosynthesis and stomatal conductance were most associated with soil moisture in the upper $(<30 \mathrm{~cm})$ zone. The different rooting habits of the 2 species were thought to be responsible for water partitioning. It is intriguing to know if similar patterns occur in shallow-rooted shrubs and associated grasses on semiarid grassland.

Broom snakeweed (Gutierrezia sarothrae Shinners.) is a conspicuous component on much of the rangelands in the western and southwestern United States. This perennial half-shrub reduces grass production (Jameson 1966, Johnson and Madrigal 1967, Ueckert 1979, McDaniel et al. 1982). It has been suggested that broom snakeweed's competitive advantage is related to its ability to extract soil water more efficiently than grasses (Ueckert 1979).

Broom snakeweed has a shallow fibrous root system (DePuit and Caldwell 1975) and the roots can access water and nutrients at the same soil depth as most perennial grasses (Pieper and McDaniel 1989). In summer drought, when leaves of most grasses are rolled, broom snakeweed leaves remain turgid. Broom snakeweed has less stomatal control over water loss than the drought resistant 
shrub Artemisia tridentata Nutt. in the cold desert rangeland (DePuit and Caldwell 1975). This may imply that broom snakeweed can maintain higher hydraulic conductivity in the soil-plant system.

We hypothesize that broom snakeweed can extract water from subsoil more effectively than grasses and therefore maintain higher physiological activity during drought. Sand dropseed (Sporobolus cryptandrus (Torr.) Gray.), an important drought resistant species in the American short-grass prairie, co-occurs with broom snakeweed and has a dense root system in the top $30 \mathrm{~cm}$ of the soil profile (Weaver 1968). Like many other grasses, sand dropseed rolls leaves during summer drought.

The objectives of this study were: (1) to evaluate soil water extraction patterns of these 2 species under pot-grown conditions; (2) to determine photosynthesis rates of the 2 species as affected by soil water deficit in both pot- and field-grown plants; and, (3) to characterize canopy development of the 2 species in the field.

\section{Materials and Methods}

Ten broom snakeweed and 10 sand dropseed plants from a rangeland plant community on the Texas Tech campus were transplanted into large plastic pots (30-cm high and $29-\mathrm{cm}$ diameter) in early March 1991. Pots contained Amarillo fine sandy loam (fineloamy, mixed, thermic Aridic Paleustalfs). The pots were watered daily to bring soil water content to field capacity, and the soil surface in each pot was covered with plastic to minimize soil evaporation. All potted plants were kept in a rain-out shelter for protection from natural precipitation during the experiment. From late April, the plants were exposed to 2 drying cycles by withholding watering. Water use by the plants was determined by weighing the pots $( \pm 1 \mathrm{~g})$ and calculating the weight loss. Total water use was monitored during rapid growth in late-April and May.

After termination of the above experiment, about 100 holes, 3.2 $\mathrm{mm}$ in diameter, were drilled on 2-cm spacings in the bottom of 10 pots containing a single broom snakeweed or sand dropseed plant. These 10 pots were placed on top of 10 other pots packed with similar soil. The holes permitted plant roots to grow into the soil in the lower pot (the roots of both species had diameters not greater than $1 \mathrm{~mm}$ ). The upper and lower pots were watered to field capacity in late May and early June and water was witheld afterward until 19 July. In the second drying cycle, the pots were watered on 29 July and allowed to dry until 12 August.

Soil water depletion from upper and lower pots was monitored by time domain reflectometry (TDR) during these 2 drying cycles (Topp et al. 1980, 1982; Ledieu et al. 1986; Dalton and Poss 1990). Stainless steel rods, $3.2 \mathrm{~mm}$ in diameter, were cut into $260-\mathrm{mm}$ lengths and used as probes. Parallel pairs of the rods were inserted horizontally into the soil 50 -mm apart at 3 depths in each pot. Soil electromagnetic capacitance and reflectance pattern were measured with a Tektronix $1502 \mathrm{C}$ cable tester (Textronix, Beaverton, Ore.) connected to the soil probes. Cable tester output was converted to dielectric constant, and soil volumetric water content was calculated from dielectric constant (Topp et al. 1980).

Volumetric water content (Qp) obtained with the time domain reflectometry was calibrated against water content determined gravimetrically. Slopes of the regression equations were not statistically different from 1 nor were the intercepts different from 0 , suggesting a 1:1 relationship $\left(r^{2}=0.95, n=27\right)$.

A field experiment was conducted simultaneously in a natural plant community on Texas Tech campus. Mature broom snakeweed and sand dropseed plants growing adjacent to each other were used in photosynthesis and water potential measurements. Photosynthesis in both pot and field studies was measured during 900 to 1000 hour with a Licor 6200 portable photosynthesis system.
A foliated stem or culm with 6 to $10 \mathrm{~cm}^{2}$ leaf area was enclosed in a 0.25 -liter chamber for 20 seconds for $\mathrm{CO}_{2}$ exchange measurement. The uppermost stems or culms with fully expanded leaves were sampled; 4 to 5 plants per species were sampled on each date for 16 dates. Photosynthetic area (1-side surface area of leaf and green stem) was estimated using a Licor 3000 area meter. The photosynthetic photon flux density was $>1.2 \mathrm{mmol} \mathrm{m}^{-2} \mathrm{~s}^{-1}$ and air temperature was $30 \pm 2^{\circ} \mathrm{C}$ during most measurements, except in April when air temperature was $25^{\circ} \mathrm{C}$. Additional diurnal measurements on photosynthesis were made in the field during subsequent rainy (15 June) and drought ( 7 July) periods. Plant water potential in the field-grown plants was measured at dawn with a Scholander-type pressure chamber using 3-5 stems or culms from different individuals of each species.

Soil volumetric water content was also monitored in the field. Stainless steel rods $6.4 \mathrm{~mm}$ in diameter and 200,400 , and $600 \mathrm{~mm}$ in length were inserted vertically into the soil at a parallel distance of $50 \mathrm{~mm}$ from the center of each rod. Four sets were installed at the study site. Soil columns with known water content were equipped with 6.4-mm rods, and a 1:1 relationship was obtained between measured soil volumetric water content and actual water content $\left(r^{2}=0.98\right.$ to 0.99$)$.

Eight plots, about $100 \mathrm{~m}^{2}$ each, were randomly established on the study site. One broom snakeweed plant and 1 sand dropseed plant were harvested from each plot on 7 sampling dates from March through August. Total green surface area of each plant (1 side) was measured with a Licor 3000 area meter.

Student $T$ tests and repeated measurement analysis (Gurevitch and Chester 1986) were used to test significant differences between species during selected time periods and to examine trends of physiological activities and soil water depletion over time. Regression analysis was used to evaluate the trend of canopy development over growth periods.

\section{Results}

By late April when the experiment began, the plants had grown for more than 40 days in the pots and were presumably established. In late April, when potted plants of the 2 species had reached similar size, whole-plant transpiration of the 2 species was similar at 1 and 2 days after watering (Fig. 1). As soil water became less available, sand dropseed transpired more than broom snakeweed. In April, sand dropseed transpired $26.6 \%$ more water over the 6-day period. In May, by the 4th day after watering, sand dropseed had transpired $28 \%$ more water than broom snakeweed. Five to 17 days after watering, however, daily transpiration by sand dropseed was nearly $100 \%$ greater (Fig. 1). In both April and May, daily differences in transpiration between species were significant $(p<0.01$, repeated measures analysis), as was the species by time interaction $(p<0.05)$. Thus, when the plants were grown in single pots, transpiration by broom snakeweed was more affected by progressive soil drying than was that of sand dropseed.

When grown in double pots, sand dropseed transpired $16.6 \%$ and $11 \%$ more soil water $(p<0.05)$ from the upper pot than broom snakeweed during the 2 drying cycles, while broom snakeweed extracted 42.3 and $72 \%$ more water $(p<0.01)$ from the lower pot than sand dropseed (Fig. 2 and 3). During the first drying cycle, upper and lower pots contributed 64.5 and $35.5 \%$ to total water use of sand dropseed, while in the case of broom snakeweed, the contributions were 48.4 and $51.6 \%$ for upper and lower pots, respectively. Similar patterns were observed during the second drying cycle (Fig. 3). At the end of the first and second drying cycles, $33 \%$ and $17 \%$ more water remained in the pots with sand dropseed than in those with broom snakeweed. Soil water depletion patterns had a significant species by time interaction with steeper slopes $(p<0.01$, repeated measures ANOVA) evident in 

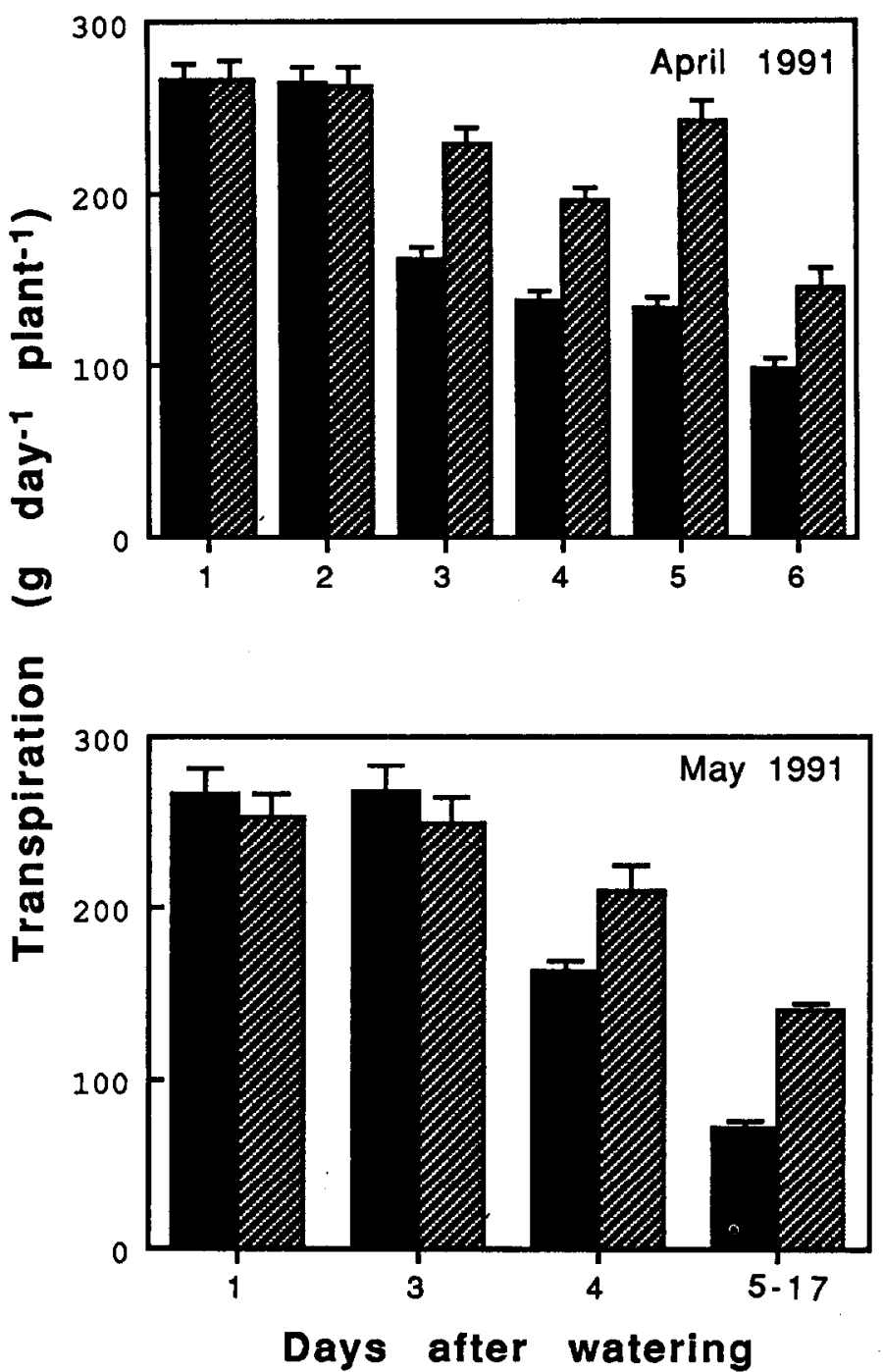

Fig. 1. Average daily whole-plant transpiration $(n=10)$ by broom snakeweed (solid bars) and sand dropseed (crosshatched bars) grown in single pots in April and May, 1991. Vertical bars represent 1 standard error. The pots were watered to field capacity 1 day before the first measurement in each month.

water use from upper pots containing sand dropseed, and in lower pots containing broom snakeweed (Fig. 2 and 3).

In the pot study, $\mathrm{CO}_{2}$ fixation rates of the 2 species were similar when soil was wet on 1 June and 19 July, but became significantly lower $(p<0.01)$ in sand dropseed from 17 June through 3 July (Fig. 4). Volumetric soil water in the upper pot was less than $0.1 \mathrm{~cm}^{3} \mathrm{~cm}^{-3}$ during this period, but soil water content in the lower pot was high $\left.>0.173 \mathrm{~cm}^{3} \mathrm{~cm}^{-3}\right)$. Similar patterns were observed in the second drying cycle (data not shown).

In the field, 3 drying periods occurred in the spring and summer of 1991 . Surface soil water content was at or below $0.1 \mathrm{~cm}^{3} \mathrm{~cm}^{-1}$ in April to early May, early July, and late July to early August (Fig. 5). During these 3 "drought" periods, sand dropseed exhibited lower dawn water potential than broom snakeweed, but its water potential was higher than broom snakeweed in the wetter periods of June (T test, $p<0.05$, Fig. 6).

At high soil water availability (mid June), peak photosynthesis of sand dropseed occurred at 1300 to 1400 hour, while broom snakeweed attained its highest photosynthetic rate at mid morning (data not shown). At low soil water availablity, both species reached maximum photosynthesis in the mid morning, and photo-
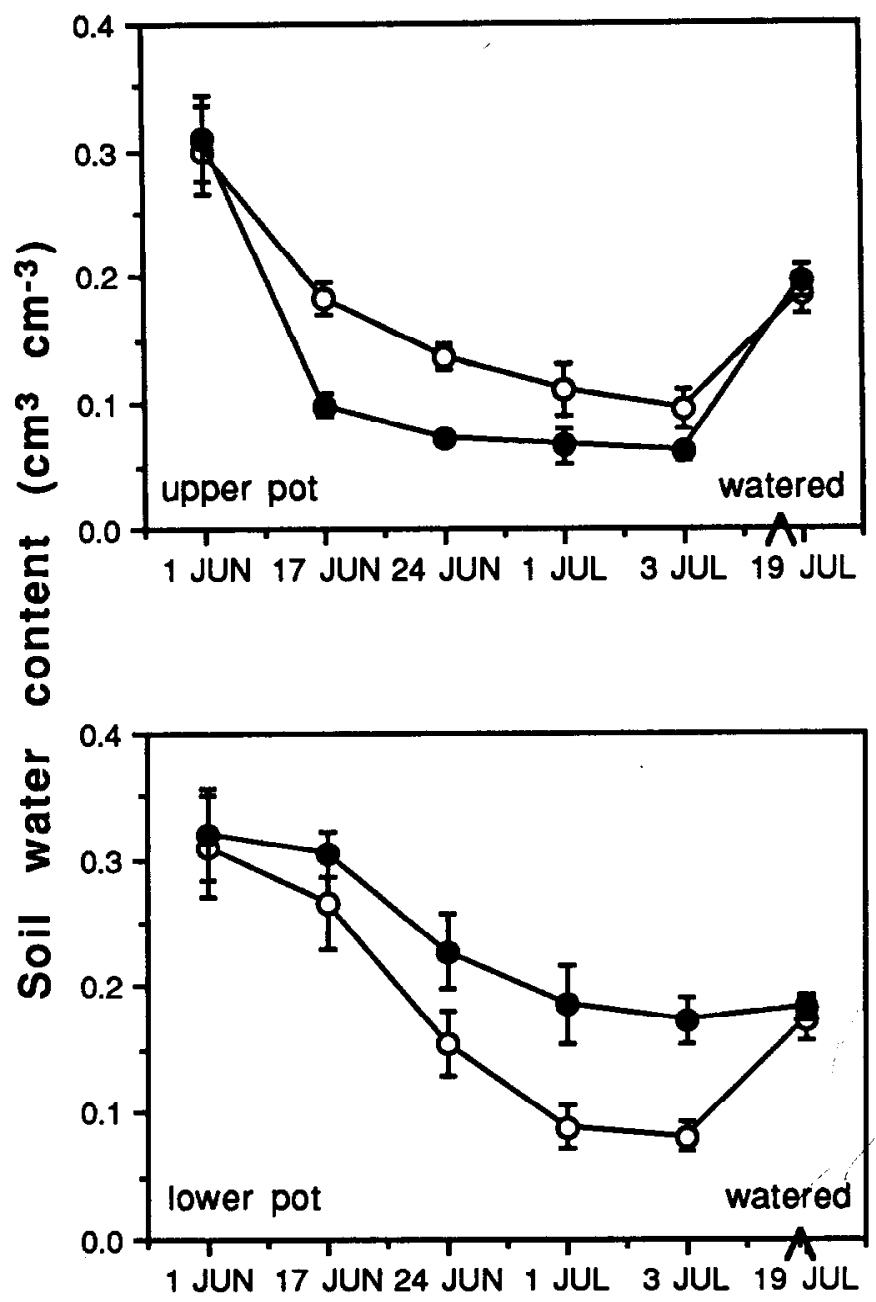

Fig. 2. Upper: Average soil water content of the upper pots ( $n=5)$ containing broom snakeweed (open circles) and sand dropseed (closed circles) grown in double pots during the first drying cycle. Lower: Average soil water content of the lower pots $(n=5)$ containing broom snakeweed (open circles) and sand dropseed (closed circles) grown in double pots during the first drying cycle. The pots were watered to field capacity on 31 May. The vertical bars represent \pm 1 standard error.

synthesis in the afternoon was sharply reduced (data not shown). During the 3 drought periods, mid morning photosynthesis in sand dropseed was significantly lower $(p<0.01)$ than in broom snakeweed (Fig. 7). During the last period of low soil water content from 30 July to 8 August, photosynthesis in both species was reduced; the trend was not significant in broom snakeweed (slope $=-0.108$, $r^{2}=0.058, p>0.1$ ), but was highly significant in sand dropseed (slope $=-0.899, r^{2}=0.99, p<0.0001$, Fig. 7). Photosynthetic capacity of sand dropseed was continuously reduced by progressive soil drying, perhaps primarily by the water deficit in the surface soil layers (Fig. 5). During the same period, water was depleted more rapidly from the $60-\mathrm{cm}$ soil depth increment than from the $20-\mathrm{cm}$ increment $(p<0.05$ for depth by time interaction, repeated measures analysis, Fig. 5). Relatively constant and higher photosynthesis in broom snakeweed during this period was probably related to greater soil water extraction from the deeper soil layers.

The general patterns of canopy development were similar for the 2 species except that broom snakeweed leaf and green stem surface area increased continuously and linearly until mid June (linear $p<0.0001, r^{2}=0.96$ ) despite periods of low soil water content, while leaf area of sand dropseed increased little from mid April until 


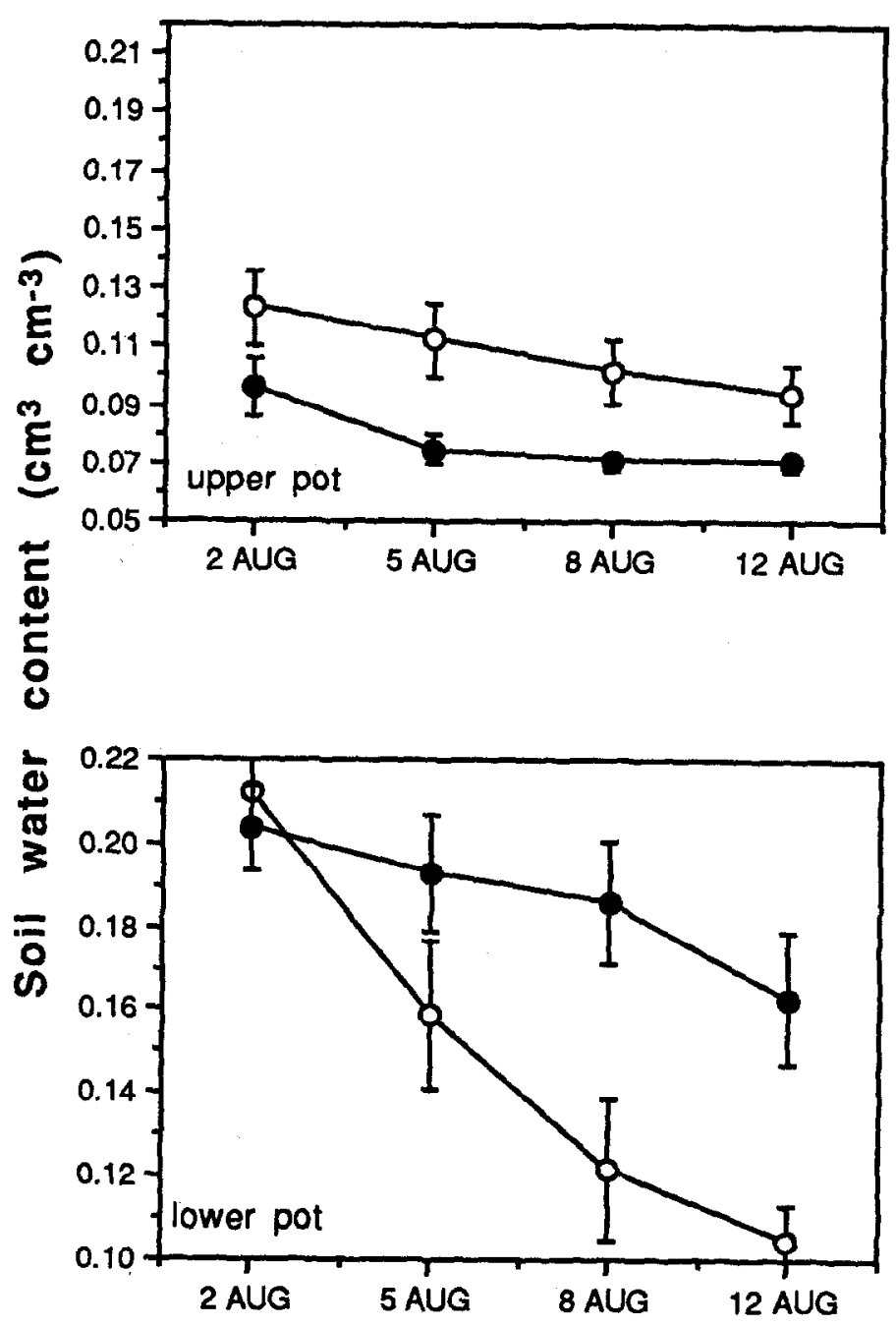

Fig. 3. Upper: Average soil water content of the upper pots $(n=5)$ containing broom snakeweed (open circles) and sand dropseed (closed circles) grown in double pots during the second drying cycle. Lower: Average soll water content of the lower pots $(n=5)$ containing broom snakeweed (open circles) and sand dropseed (closed circles) grown in double pots during the second drying cycle. The pots were watered to field capacity on 29 July. The vertical bars represent \pm 1 standard error.

early May (linear $p<0.001, r^{2}=0.88$; quadratic $p<0.05$ ) (Fig. 8). Photosynthetic surface area of both species declined after June.

\section{Discussion}

When root systems were confined to a single pot, $30-\mathrm{cm}$ deep, sand dropseed extracted more water from the soil than broom snakeweed as drought developed. This may reflect a greater root density of sand dropseed than broom snakeweed in the soil surface. In the field, when soil water availability was high in the soil surface in June, sand dropseed had higher dawn water potential than broom snakeweed, again indicating an effective root system in the topsoil. This agrees with the research of Cald well et al. (1987) and Polley et al. (1992) who found that root length or biomass of the grasses in the topsoil is much greater than that of the shrubs. When both species were grown in the double pots, broom snakeweed extracted more water from greater soil depths than sand dropseed, reflecting greater root penetration of broom snakeweed in the lower pots.

When broom snakeweed plants were grown in single pots, the development of a deep root system was precluded, and the poten-

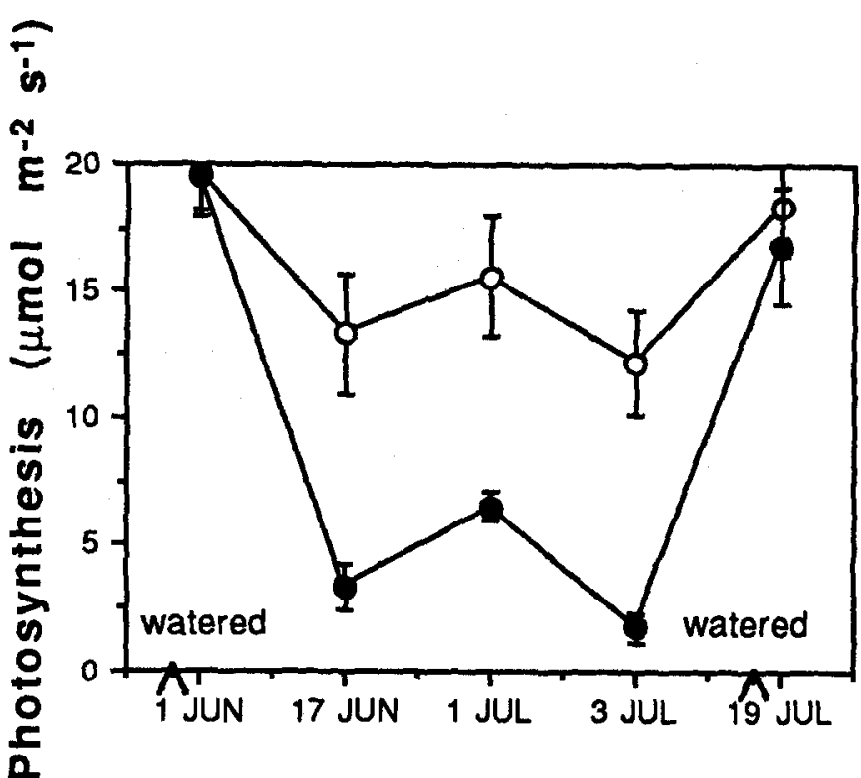

Fig. 4. Photosynthesis of broom snakeweed (open circles) and sand dropseed (closed circles) during the first drying cycle. The vertical bars represent \pm 1 standard error $(n=5)$.

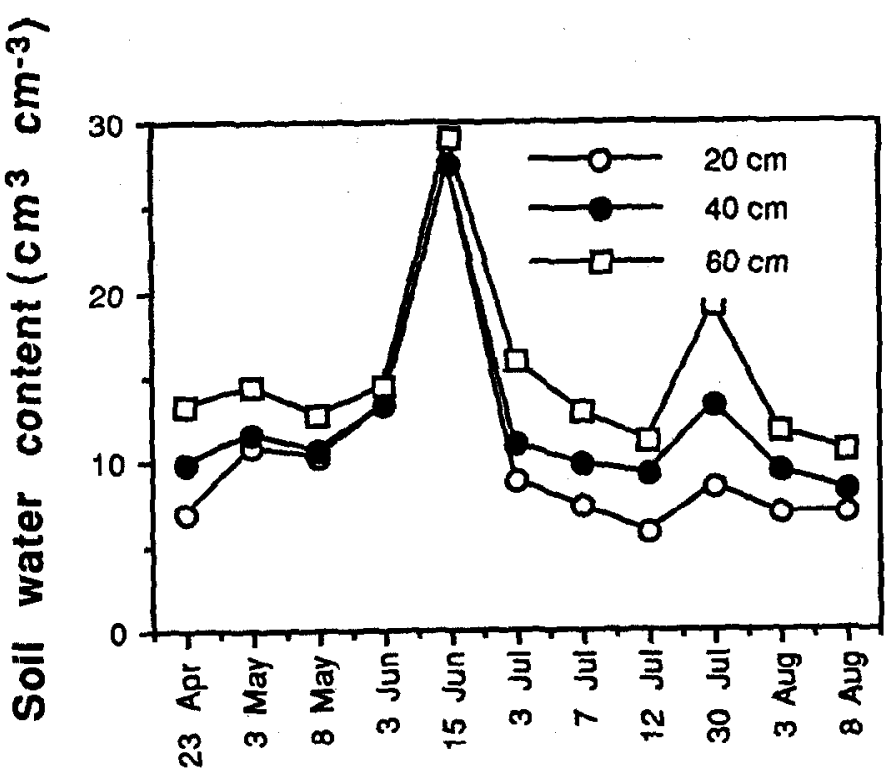

Fig. 5. Avermge volumetric soil water content at 3 soil depths during the growing season in the field. The standard errors of the mean are smaller than the symbols $(n=4)$.

tial for water absorption could not be realized. Several reports have described the greater effectiveness of water uptake by roots in the profile under limited water supply (Taylor and Klepper 1973, Proffitt et al. 1985, Sharp and Davies 1985, Sheffer et al. 1987). This has been attributed to wetter subsoil, less competition due to reduced root density at depth, and deeper roots being young (Taylor and Klepper 1973). In this study, water depletion by broom snakeweed was similar in the top and subsoil. At the end of the first drying cycle, soil water was depleted to 0.095 and $0.081 \mathrm{~cm}^{3} \mathrm{~cm}^{-3}$ for the upper and lower pot, respectively. The values were 0.094 and 0.105 for the second drying cycle. This reveals an extraordinary water absorption capacity of broom snakeweed roots. In 


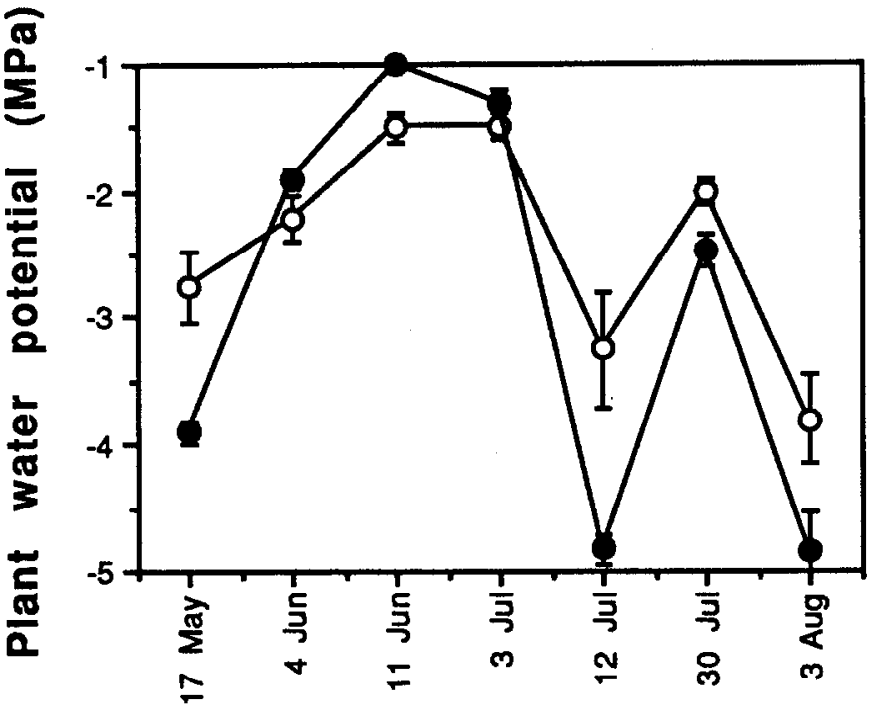

Fig. 6. Plant water potential at dawn in broom snakeweed (open circles) and sand dropseed (closed circles) grown in the field during growing season. The vertical bars represent \pm 1 standard error $(n=3$ to 5$)$.

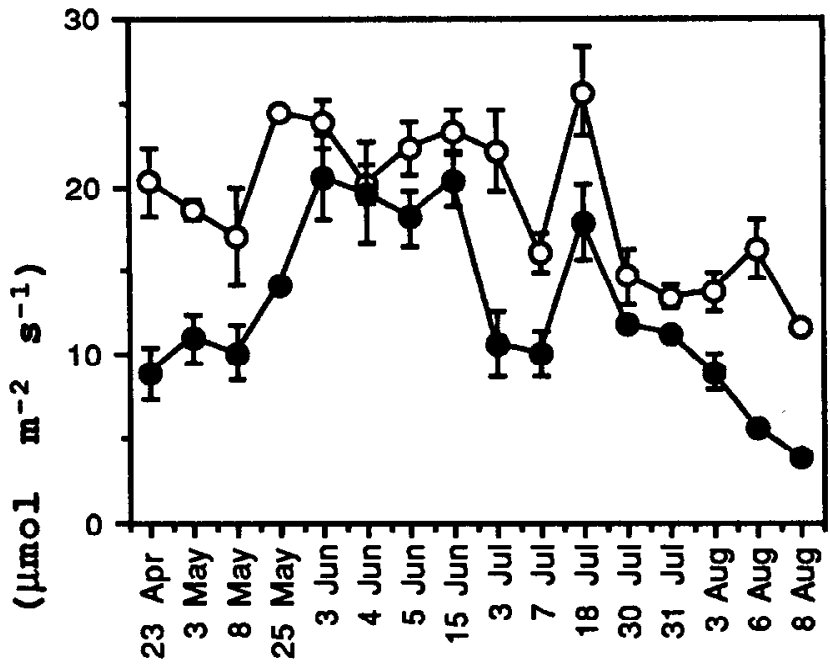

$n$
-1
0
0
0
1
0
0
0
0
+4
0
0
0
0

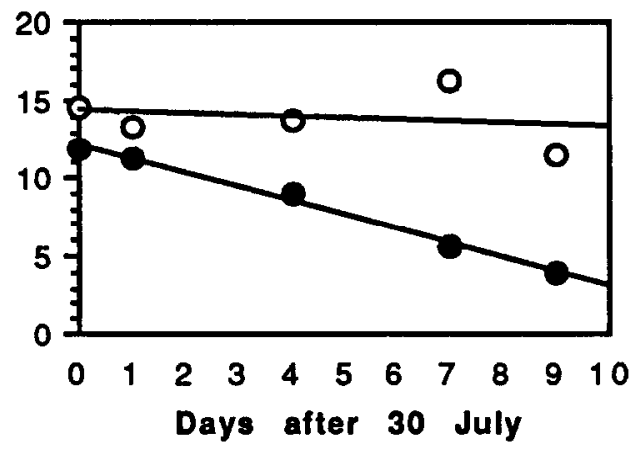

Fig. 7. Photosynthesis in broom snakeweed (open circles) and sand dropseed (closed circles) grown in the field during the growing season. The measurements were taken during 900 to 1000 hours on sunny days. The vertical bars represent \pm 1 standard error $(n=4$ to 5$)$. The lower, smaller figure shows photosynthesis of the 2 species as affected by the third drought period from 30 July to 8 August. Note that photosynthesis was reduced linearly in sand dropseed, but not in broom snakeweed.

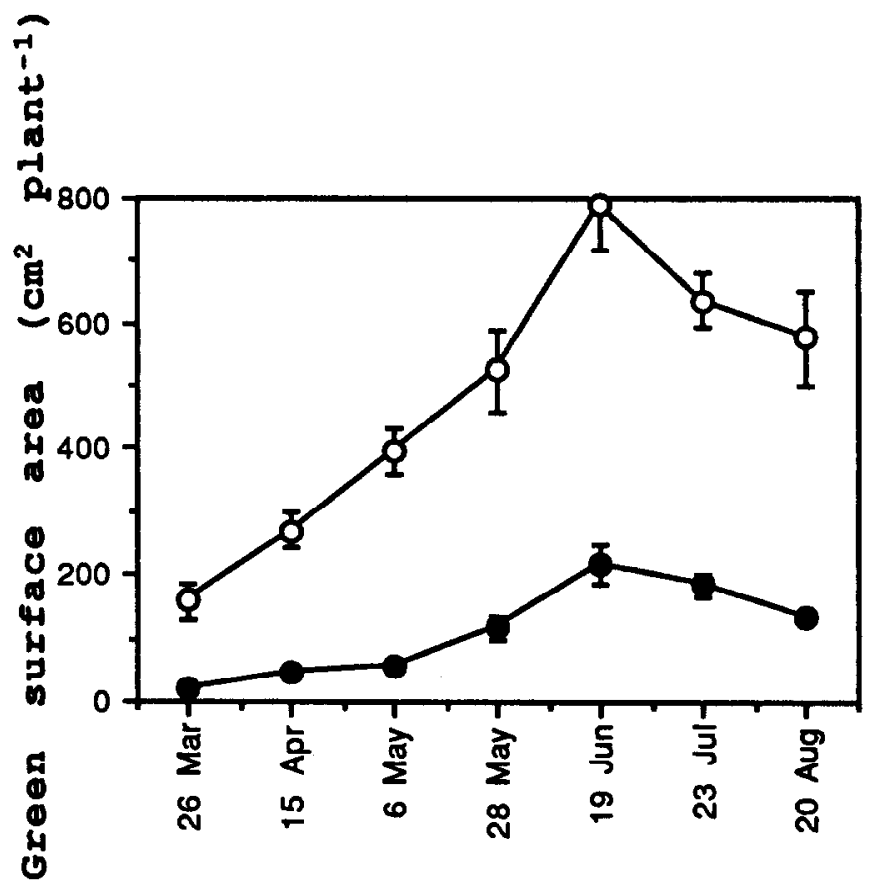

Fig. 8. Total green surface area (1 side) per broom snakeweed (open circles) and sand dropseed (closed circles) plant grown in the field during the growing season. The vertical bars represent \pm 1 standard error $(n=8)$.

contrast, sand dropseed was less able to exploit the subsoil. At the end of the first drying cycle, water content in the lower pot was as high as $0.173 \mathrm{~cm}^{3} \mathrm{~cm}^{-3}$, while the upper pot was very dry at 0.061 $\mathrm{cm}^{3} \mathrm{~cm}^{-3}$ (Fig. 2).

Photosynthesis in sand dropseed was reduced by low soil water content $(\mathrm{Q} p<0.1)$ in the upper pot, but the effect was much less in broom snakeweed because the roots extracted both top and bottom soil layers. These results were substantiated by field measurements during periods of limited soil water availability.

In the field, when water content in the upper soil was only 0.1 $\mathrm{cm}^{3} \mathrm{~cm}^{-3}$ during spring, leaf area development and photosynthesis of sand dropseed were both reduced by water deficit, but leaf area accumulation by broom snakeweed was more rapid. It appears that sand dropseed mainly depends on water in the shallow soil layers for growth, while growth of broom snakeweed was less affected by water deficit in the upper soil layers. In spring, most plant species have limited root growth in the subsoil, but evergreen species such as broom snakeweed already have substantial biomass both above- and below-ground. Our observations indicate that root systems of broom snakeweed seedlings penetrate below $30-\mathrm{cm}$ subsoil around late April. Competition from other species for water and nutrients below the $30-\mathrm{cm}$ depth is probably minimal, favoring broom snakeweed growth. Brown and Archer (1990) found that mesquite plants began partitioning soil moisture with grasses early in their life cycle when competition from grasses was intense in the upper soil layers. Early water partitioning with grasses was also evident in this shallow-rooted half-shrub. Since the surface soil was drier than the deeper soil layers (Fig. 5), this early water partitioning allowed broom snakeweed to preempt water from where it was most available and to maintain a higher growth rate. When soil water content was low in July and August, leaf area of both species declined (Fig. 8). Leaf shedding of snakeweed under summer drought has been reported (DePuit and Caldwell 1975). As soil water deficit developed, water absorption from deeper in the soil profile became insufficient to supply or meet potential transpiration (Proffitt et al. 1985). Stomatal conductance 
of broom snakeweed remained relatively high ( $50 \%$ of that in June, data not shown), so leaves from the lower stems were shed in order to maintain a balance between water supply and transpirational demand.

In the rainy season (June), a small rainfall event of $1-2 \mathrm{~cm}$ can only wet the upper layers of a dry soil unless the soil is very sandy (Passioura 1988). Since sand dropseed could take up water more effectively from the topsoil, it had higher water potential than broom snakeweed during this period (Fig. 6). Desert herbaceous perennials are better able to utilize summer rains than the woody perennials (Ehleringer et al. 1991). This study supports this generalization, and suggests that different responses to summer rainfal in these 2 species are related to their water extraction patterns.

Total carbon gain is a primary factor in determining the success of a plant species in its given environment (Schulze 1982). Seasonal $\mathrm{CO}_{2}$ fixation of these 2 species was closely related to soil water acquisition patterns. In the warm arid regions, $\mathrm{C} 4$ species, by virtue of higher temperature optima for photosynthesis and growth, usually perform better than C3 species (Ludlow 1985). This is probably true when the soil is moist following summer precipitation (Osmond et al. 1982). Water in the surface soil often has shorter duration than the subsurface water (Richards 1986). During drought periods, as the soil dried from the surface, less effective water uptake from the subsoil led to a reduced carbon gain in sand dropseed; but had less effect on broom snakeweed. This may enable broom snakeweed to maintain a higher carbon gain under drought conditions, and compete successfully with sand dropseed on semiarid rangelands.

\section{Literature Cited}

Brown, J.R., and S. Archer. 1990. Water relations of a perennial grass and seedling vs adult woody plants in a subtropical savanna, Texas. Oikos 57:366-374.

Caldwell, M.M., J.H. Richards, J.H. Manwaring, and D.M. Eissenstat. 1987. Rapid shifts in phosphate acquisition show direct competition between neighboring plants. Nature 327:615-616.

Dalton, F.N., and J.A. Poss. 1990. Soil water content and salinity assessment for irrigation scheduling using time-domain reflectometry: principles and applications. Acta Horticulturae 278:381-393.

Depuit, E.J., and M.M. Caldwell. 1975. Gas exchange of three cool semidesert species in relation to temperature and water stress. J. Ecol. 68:835-858.

Ehleringer, J.R., S.L. Phillips, W.S.F. Schuster, and D.R. Sandquist. 1991. Differential utilization of summer rains by desert plants. Oecologia (Berlin) 88:430-434.

Gurevitch, J., and S.T. Chester, Jr. 1986. Analysis of repeated measures experiments. Ecology 67:251-255.

Jameson, D.A. 1966. Competition in a blue grama-broom snakeweedactinea community and responses to selective herbicides. J. Range Manage. 19:121-124.
Johnsen, T.N., and R.M. Madrigal. 1967. Broom snakeweed competition with grasses and a shrub in the greenhouse, p. 41. In: Res. Prog. Rep., Western Weed Control Conf.

Ledieu, J., P. De Ridder, P. De Clerck, and S. Dautrebande. 1986. A method of measuring soil moisture by time-domain reflectometry. $\mathbf{J}$. Hydrol. 88:319-328.

Ludlow, M.M. 1985. Photosynthesis and dry matter production in C3 and $\mathrm{C} 4$ pasture plants, with special emphasis on tropical $\mathrm{C} 3$ legumes and $\mathrm{C4}$ grasses. Aust. J. Agr. Res. 12:557-572.

McDaniel, K.C., R.D. Pieper, and G.B. Donart. 1982. Grass response following thinning of broom snakeweed. J. Range Manage. 35:219-222.

Osmond, C.B., K. Winter, and H. Ziegler. 1982. Functional significance of different pathways of $\mathrm{CO}_{2}$ fixation in photosynthesis, p. 479-547. In: O.L. Lange, P.S. Nobel, C. B. Osmond, and H. Ziegler (eds.), Physiological plant ecology. II. Springer, Berlin, Heidelberg and New York.

Passioura, J.B. 1988. Water transport in and to roots. Annu. Rev. Plant Physiol. Plant Molecular Biol. 39:245-265.

Pieper, R.D., and K.C. McDaniel. 1989. Ecology and management of broom snakeweed, p. 1-11. In: E.W. Huddleston, and R.D. Pieper (eds.), Snakeweed: Problems and perspectives. College of Agriculture and Home Economics, New Mexico State Univ., Las Cruces.

Polley, H.W., H.B. Johnson, and H.S. Mayeux. 1992. Determination of root biomass of three species grown in a mixture using stable isotopes of carbon and nitrogen. Plant and Soil 142:97-106.

Proffitt, A.P.B., P.B. Berliner, and D.M. Oosterhuis. 1985. A comparative study of root distribution and water extraction efficiency by wheat grown under high- and low-frequency irrigation. Agron. J. 77:655-662.

Richards, J.H. 1986. Root form and depth distribution in several biomes, p. 82-97. In: D. Carlisle, W.L. Berry, I.R. Kaplan, and J.R. Watterson (eds.), Mineral exploration: Biological systems and organic matter. Vol. V. Prentice-Hall, Englewood Cliffs, N.J.

Sala, O.E., R.A. Golluscio, W.L. Lauenroth, and A. Soriano. 1989. Resource partitioning between shrubs and grasses in the Patagonian steppe. Oecologia 81:501-505.

Schulze, E.D. 1982. Plant life forms and their carbon, water and nutrient relations, p. 616-676. In: O.L. Lange, P.S. Nobel, C.B. Osmond, and H. Ziegler (eds.), Physiological plant ecology. II. Springer, Berlin, Heidelberg and N.Y.

Sharp, R.E., and W.J. Davies. 1985. Root growth and water uptake by maize plants in drying soil. J. Exp. Bot. 36:1441-1456.

Sheffer, K.M., J.H. Dunn, and D.D. Minner. 1987. Summer drought response and rooting depth of three cool-season turfgrasses. HortScience 22:296-297.

Taylor, H.M., and B. Klepper. 1973. Rooting density and water extraction patterns for corn (Zea mays L.). Agron. J. 65:965-968.

Topp, G.C., J.L. Davies, and A.P. Annan. 1980. Electromagnetic determination of soil water content: measurements in coaxial transmission lines. Water Resources Res. 16:574-582.

Topp, G.C., J.L. Davies, and A.P. Annan. 1982. Electromagnetic determination of soil water content using TDR: I. Applications to wetting fronts and steep gradients. Soil Sci. Soc. Amer. J. 46:672-678.

Ueckert, D.N. 1979. Broom snakeweed (Xanthocephalum sarothrae) effect on shortgrass forage production and soil water depletion. J. Range Manage. 33:216-220

Weaver, J.E. 1968. Prairie plants and their environment. University of Nebraska Press, Lincoln, p. 252. 